\title{
Adhesive Behavior of the Pack-Borided AISI 304L Steel with Microwave Hybrid Heating
}

\author{
Dilek Arslan ${ }^{1 *}$ (iD), Recep Onur Uzun ${ }^{2}$ (iD) \\ 1* Graduate School of Applied and Natural Sciences, Department of Mechanical Engineering, Manisa Celal Bayar \\ University, 45140, Manisa, Turkey \\ ${ }^{2}$ Hasan Ferdi Turgutlu Technology Faculty, Department of Mechanical Engineering, Manisa Celal Bayar \\ University, 45400, Manisa, Turkey \\ *da.dilekarslan@gmail.com \\ *Orcid: 0000-0003-0198-0787
}

Received: 15 November 2020

Accepted: 20 February 2021

DOI: $10.18466 /$ cbayarfbe. 826118

\begin{abstract}
AISI 304L stainless steel material was pack-borided with microwave hybrid heating method at temperatures of 850,900 and $950{ }^{\circ} \mathrm{C}$ for 2,4 and 6 hours. The morphology of the boride layer formed on the surface of the samples was examined by an optical microscope. The X-ray diffraction (XRD) analysis showed the presence of the $\mathrm{FeB}, \mathrm{Fe}_{2} \mathrm{~B}, \mathrm{Cr}_{2} \mathrm{~B}$ and $\mathrm{Ni}_{2} \mathrm{~B}$ phases on the surface of the borided samples. The Daimler-Benz Rockwell-C adhesion test was carried out to evaluate the adhesive strength of the boride layer to the substrate material. The tests were repeated at least 3 times for each of the samples packborided at all process temperatures and times. After the adhesion tests, macro and SEM images of indentation traces were taken. By analysing the indentation craters, it has been determined whether the damages are acceptable or not with reference to the VDI 3198 standard. The indentation craters formed on the surfaces of the samples were pack-borided at $850{ }^{\circ} \mathrm{C}$ for all process times, at $900{ }^{\circ} \mathrm{C}$ for 2 and 4 hours, and at $950{ }^{\circ} \mathrm{C}$ for 2 hours have the best adhesion quality in the HF1 category of the VDI 3198 norm. The pack-boriding treatment with microwave hybrid heating contributed positively to the adhesion strength, but in additions to this, the test results revealed that adhesion decreased with increasing boriding temperature and time.
\end{abstract}

Keywords: Adhesion test, Daimler-Benz Rockwell-C, microwave hybrid heating, pack-boriding, VDI 3198 norm.

\section{Introduction}

Boriding changes the microstructure and composition of the material surface by thermochemical diffusion of boron atoms to the material surface; creates a functional surface layer with optimum surface properties. High hardness and low friction coefficient are two important mechanical properties that the boride layer that forms as a result of boriding gives the material surface. Thanks to these features, the major problem that shortens or ends the service life of engineering materials, namely surface wear, is prevented. Morón et al. [1], in their study, reduced the friction coefficient of the AISI H13 steel, which was initially in the range of $0.64-0.71$, to 0.10 0.11 values, which they applied pack-boriding at $950{ }^{\circ} \mathrm{C}$ for 6 hours, and increased the abrasion resistance by 23 times in the lubricated environment. Kayali et al. [2] achieved a 30-fold reduction in the abrasion rate of the AISI 316L stainless steel alloy that borided with 2 and 6 hours of hold times at 800 and $900{ }^{\circ} \mathrm{C}$. Material surfaces working in contact with each other are connected with micro-welds after a while. With the ongoing relative movement breaking these bonds, the relatively less hard material is transferred to the opposite element, thus creating gaps on the less hard material surface and protrusions on the other surface. This surface wear resulting in material loss is called adhesive wear. Surface hardening is the leading measure to be taken to increase the adhesive strength on the material surface. However, conventional surface hardening methods cannot be applied to austenitic stainless steels. Because they protect their austenitic microstructure from room temperature to high temperatures. For this reason, boriding is widely preferred in order to increase surface hardness due to its easy applicability and economy. In their study, Alias et al. [3] increased the surface hardness of AISI 304 austenitic stainless steel alloy 5 times with the pack-boriding process at $850{ }^{\circ} \mathrm{C}$ and for 8 
hours. In many studies in the literature, high surface hardness values have been obtained in different types of steels as well as austenitic stainless steels by applying boriding process [4-19]. Thanks to boriding, the surface hardness of the material not only increases; since the chemical reactivity of boron against oxygen is high, a thin oxide film forms on the boride layer. This layer acts as a solid lubricant, reducing the friction coefficient [20, 21]. Boride layer has a low tendency to cold weld so it does not need to be oiled to prevent adhesive wear. Taktak ve Tasgetiren [22] subjected AISI H13 and AISI 304 steels to boriding in a slurry salt bath at $800-950{ }^{\circ} \mathrm{C}$ for 3, 5 and 7 hours. The quality of adhesion strength of the boride layers formed on both steel materials borided at $800{ }^{\circ} \mathrm{C}$ is in the HF1 and HF2 category and is very high. However, it has been reported that the adhesion quality of the boride layer decreases as the process temperature and time increases. The increase in the quality of adhesion strength between the boride layer and the matrix material increases the adhesion resistance. As the adhesion quality deteriorates, crack formation starts due to internal stresses and progresses, resulting in delaminations on the material surface.

Krelling et al. [23] applied pack-boriding process on AISI 1020 steel with a 4 hour retention time at $1000^{\circ} \mathrm{C}$. After Rockwell C indentation tests, they obtained HF1 quality adhesion strength between the boride layer and the substrate and reported the result that the boriding gave a good adhesion resistance.

This study aimed to increase the adhesion resistance by using a microwave hybrid heating system as a thermal energy source for pack-boriding process. The adhesion strength analysis of the boride layer formed on the surface of AISI 304L stainless steel samples, on which pack boriding was applied for 2, 4 and 6 hours at 850, 900 and $950{ }^{\circ} \mathrm{C}$ temperatures with microwave hybrid heating methods, to the matrix material was evaluated by Daimler-Benz Rockwell-C adhesion test.

\section{Experimental Procedure}

\subsection{Pack-boriding process with microwave hybrid heating}

The test specimens were manufactured from AISI 304L stainless steel material, whose standard chemical composition is given in Table 1, with a diameter of $20 \mathrm{~mm}$ and a height of $10 \mathrm{~mm}$. The samples were ground up to 1200 grid and subjected to ultrasonic bath for 30 minutes before the thermochemical treatment. The pack-boriding treatments were carried out in a microwave furnace at 850,900 ve $950{ }^{\circ} \mathrm{C}$ for 2,4 and 6 $\mathrm{h}$, and the samples were allowed to cool in the open air at the end of the process. Commercial Ekabor-II powder was used as the boriding agent. The samples were placed in AISI 304 stainless steel containers and covered with boriding powder. The schematic picture of the microwave sintering furnace with the microwave hybrid heating mechanism where the pack-boriding process takes place is given in Figure 1. Heating in the microwave heating system is provided by both microwave radiation and convection heat transfer mechanisms. That's why hybrid heating is in question. Thanks to the microwave absorbing plates around the boriding crucible, which is heated volumetrically by microwave radiation, convection heat transfer accompanies it. This hybrid heating system, which increases thermal diffusion and saves energy with homogeneous heating and homogeneous temperature distribution, is an improvement innovation in the packboriding process. The morphology of the boride layer formed on the sample surfaces after the boriding process was examined by optical microscope at x200 magnifications, and the phases formed in the layer were determined by XRD. The samples for microstructural analyses were sanded with $\mathrm{SiC}$ abrasive paper up to 1200 grid, polished with $1 \mu \mathrm{m}$ diamond polishing solution, and etched with Glyceregia solution.

\subsection{Adhesion test and characterization}

The Daimler-Benz Rockwell-C adhesion test was used to evaluate the adhesion of boride layers. The Rockwell$\mathrm{C}$ indentation test is specified according to the VDI 3198 norm, as a quality test for coated materials. In this test, the plastic deformation that occurs as a result of the penetration of the conical end indenter into the surface of the coated material determines the adhesion quality of the coating. The thickness of the sample must be at least 10 times greater than the indentation depth. The type and volume of damage to the coating gives information about the adhesion of the coating layer at first glance and the fragility secondly. The principle of the method and the quality categories of the adhesion strength of the damage in the coating layer after the test are shown in Figure 2. Grades between HF1-HF4 indicate the presence of sufficient adhesion in the coating layer; the HF5 and HF6 categories indicate insufficient adhesion strength, ie failure of the coating $[24,25]$. Indentation processes, BMS 200-RB brand Rockwell hardness measurement device in accordance with VDI 3198 indentation test standards, with $120^{\circ}$ conical tip and $150 \mathrm{~kg}$ load after repeating 3 times, the craters formed on the sample surfaces were examined using a stereo microscope and SEM (scanning electron microscope). By analyzing the cracks, delaminations and fractures occurring in the boride layer of each sample, it was determined whether the damages were acceptable by referring to the damage categories (HF1HF6) of the VDI 3198 indentation test standard in Figure 2. 
Table 1. AISI 304L stainless steel material chemical composition

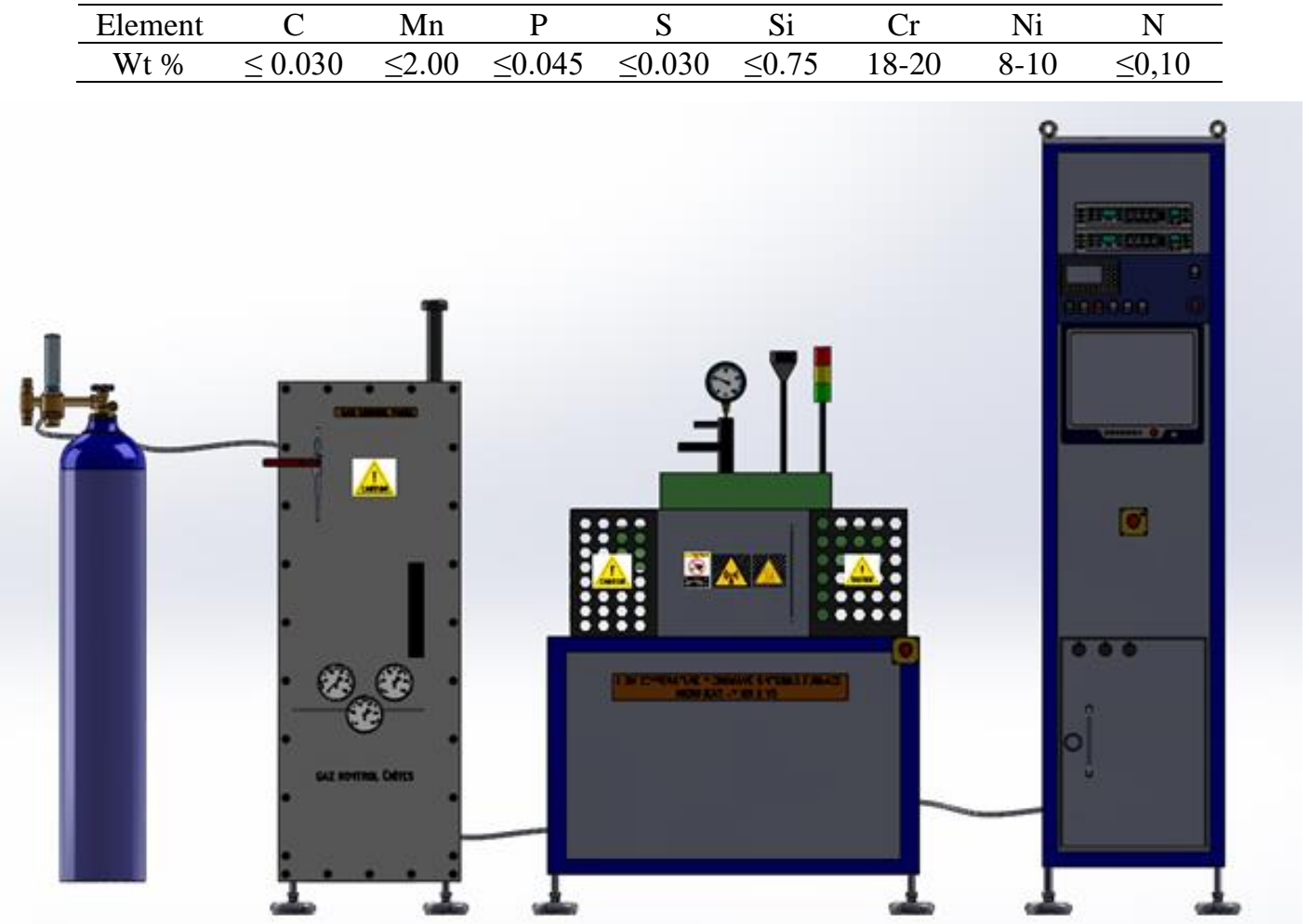

Figure 1. Schematic picture of microwave sintering furnace
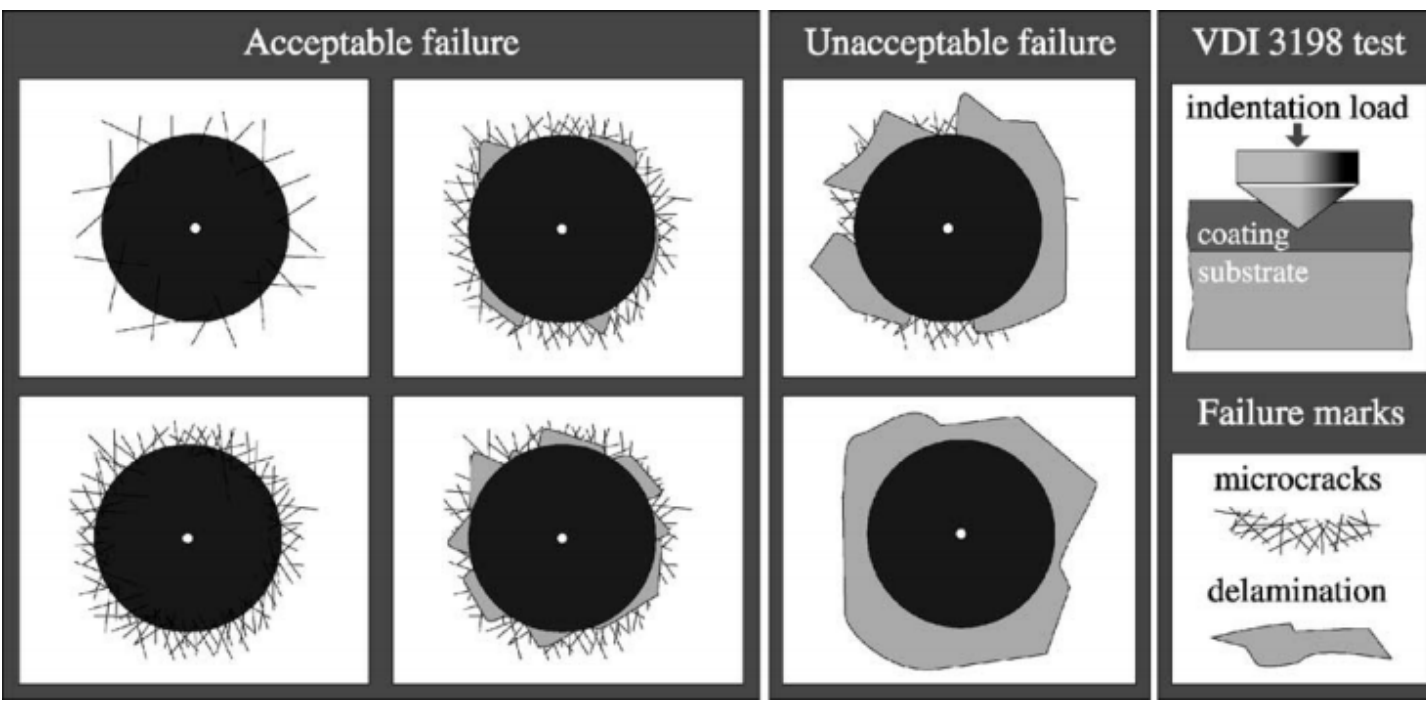

Failure marks

microcracks

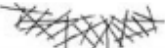

delamination

Figure 2. VDI 3198 indentation test adhesion quality classification [24]

\section{Results and Discussion}

\subsection{The Characterization of Boride Layers}

In the optical microscope images, the boride layers formed after boriding on the cylindrical samples of AISI $304 \mathrm{~L}$ stainless steel are bilayer $\left(\mathrm{Fe}_{2} \mathrm{~B}+\mathrm{FeB}\right)$ and can be clearly distinguished from the base material. As can be seen from Figure 3, the increase in process temperature and retention time increased the boride layer thickness. Due to the high amount of alloying elements in the structure of AISI 304L stainless steel material, the boride layer formed on its surface has flat and smooth morphology. In Figure 4, XRD analysis showed the presence of $\mathrm{Cr}_{2} \mathrm{~B}$ and $\mathrm{Ni}_{2} \mathrm{~B}$ phases in the boride layer besides $\mathrm{Fe}_{2} \mathrm{~B}$ and $\mathrm{FeB}$ phases. 


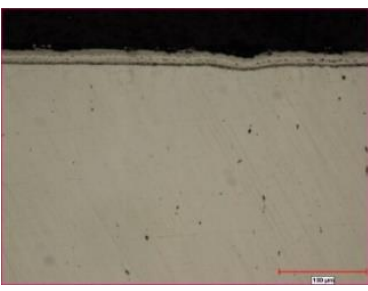

$850{ }^{\circ} \mathrm{C}-2 \mathrm{~h}$

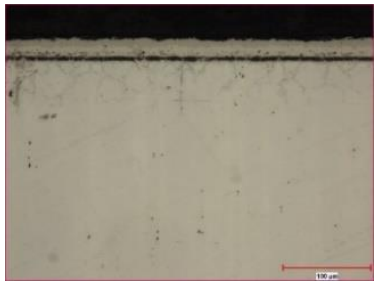

$900{ }^{\circ} \mathrm{C}-2 \mathrm{~h}$

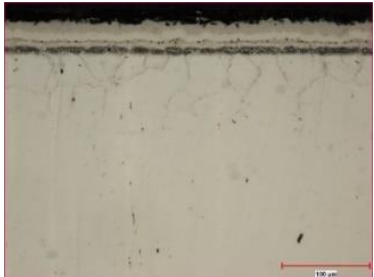

$950{ }^{\circ} \mathrm{C}-2 \mathrm{~h}$

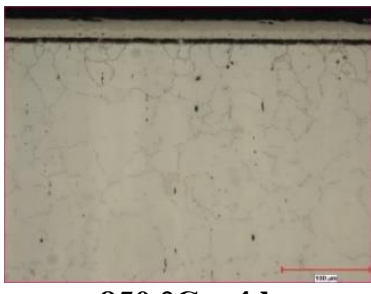

$850{ }^{\circ} \mathrm{C}-4 \mathrm{~h}$

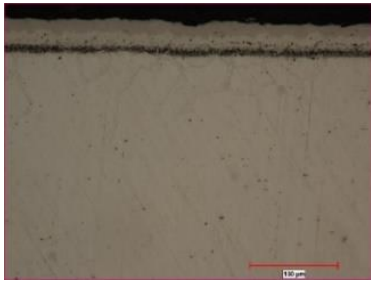

$900{ }^{\circ} \mathrm{C}-4 \mathrm{~h}$

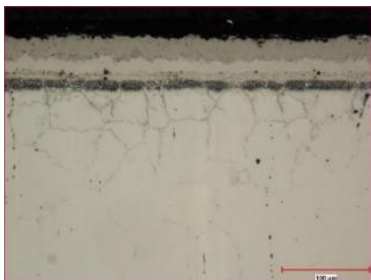

$950{ }^{\circ} \mathrm{C}-4 \mathrm{~h}$

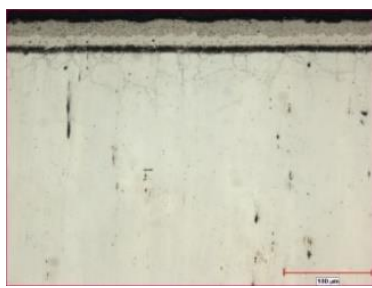

$850{ }^{\circ} \mathrm{C}-6 \mathrm{~h}$

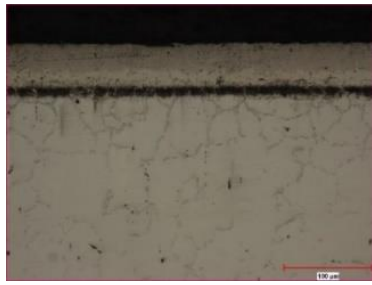

$900{ }^{\circ} \mathrm{C}-6 \mathrm{~h}$

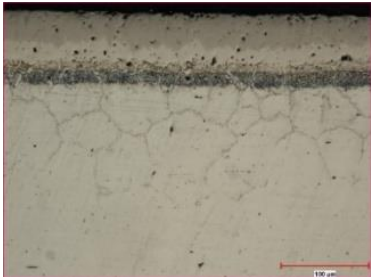

$950{ }^{\circ} \mathrm{C}-6 \mathrm{~h}$

Figure 3. Optical microscope images of AISI 304L samples pack-borided at process temperatures and times with microwave hybrid heating: x200 magnification

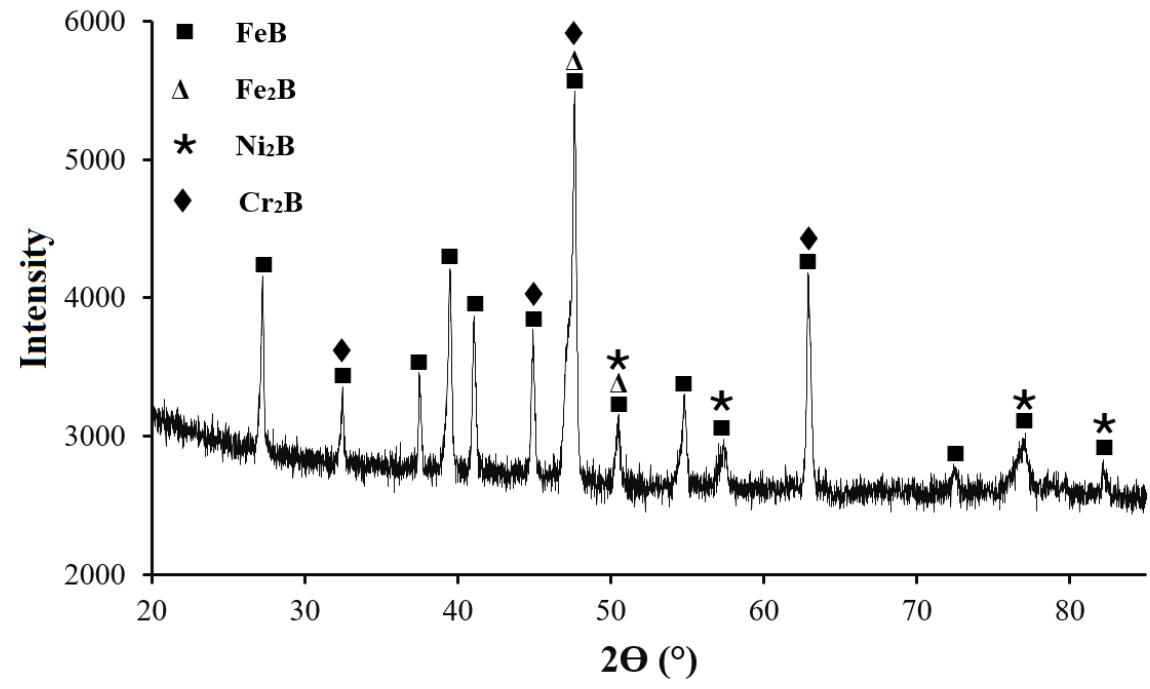

Figure 4. XRD pattern of the pack-borided AISI 304L steel at $900{ }^{\circ} \mathrm{C}$ for 6 hours

\subsection{The adhesion resistance of boride layer}

Macro and SEM images of the indentation traces taken after the adhesion tests on AISI 304L stainless steel samples pack-borided with microwave hybrid heating method are given in Figure 5-18. Whether the appearance of damage occurring in the adhesion test results is acceptable or not was evaluated according to the VDI 3198 norm. In Figure 5, the indentation craters formed on AISI 304L stainless steel sample surfaces, which are pack-borided at $850{ }^{\circ} \mathrm{C}$ for all process periods, at $900{ }^{\circ} \mathrm{C}$ for 2 and 4 hours, and at $950{ }^{\circ} \mathrm{C}$ for 2 hours by microwave hybrid heating method, are as in the HF1 category of the VDI 3198 and are acceptable. HF1 has the best adhesion quality. Therefore, the adhesion strength of the samples pack-borided at these process temperatures and times is quite good. However, as can be seen in Figure 6, the boride layer on the surface of one of the samples, which was pack-borided at $900{ }^{\circ} \mathrm{C}$ for 6 hours, was broken up during the indentation test, and in another there are spallings. A spalling was observed in the boride layer of one of each sample which was pack-borided at $950{ }^{\circ} \mathrm{C}$ for 4 and 6 hours. Damages in these samples are of HF5 quality and are unacceptable. 


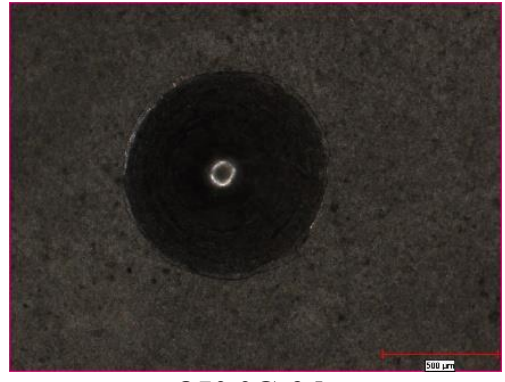

$850{ }^{\circ} \mathrm{C}-2 \mathrm{~h}$

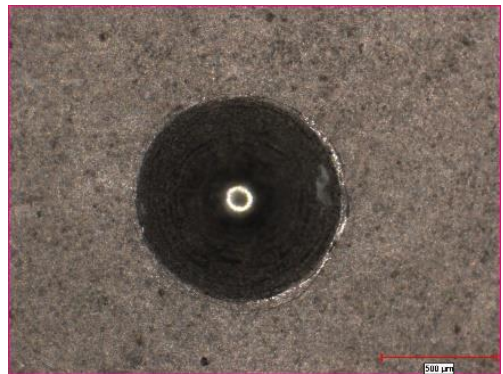

$900{ }^{\circ} \mathrm{C}-2 \mathrm{~h}$

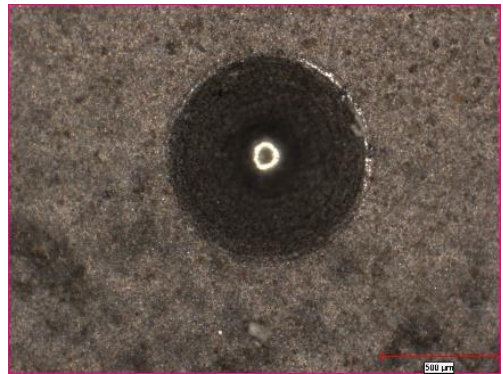

$950{ }^{\circ} \mathrm{C}-2 \mathrm{~h}$

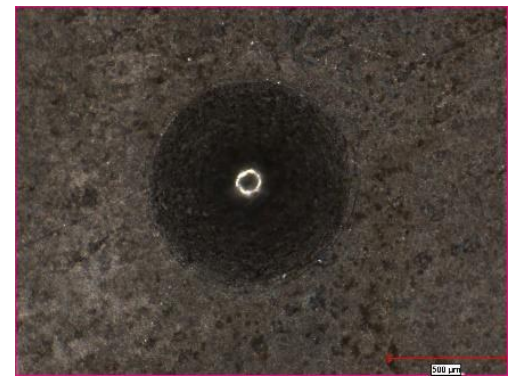

$850{ }^{\circ} \mathrm{C}-4 \mathrm{~h}$

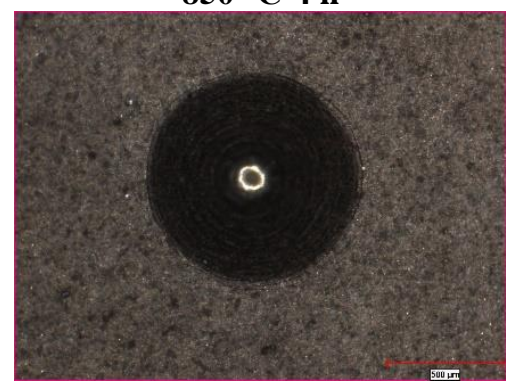

$900{ }^{\circ} \mathrm{C}-4 \mathrm{~h}$

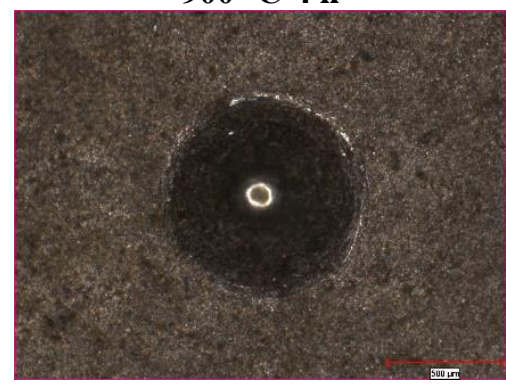

$950{ }^{\circ} \mathrm{C}-4 \mathrm{~h}$

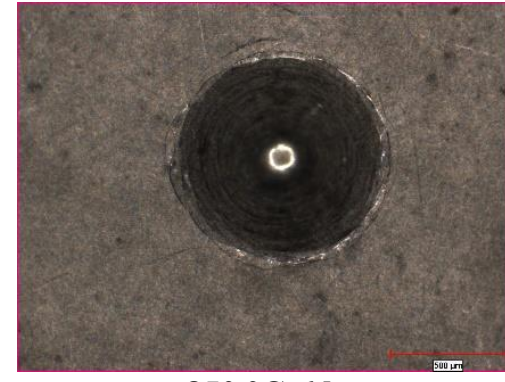

$850{ }^{\circ} \mathrm{C}-6 \mathrm{~h}$

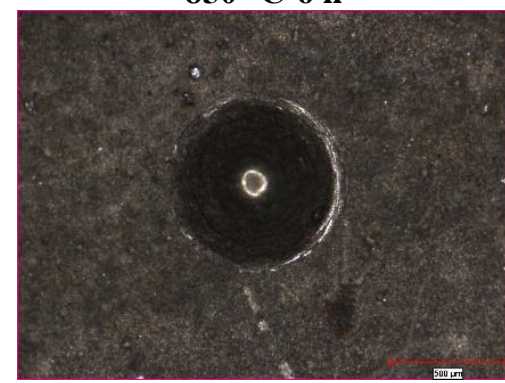

$900{ }^{\circ} \mathrm{C}-6 \mathrm{~h}$

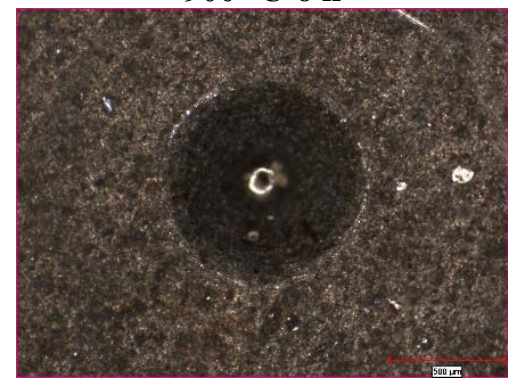

$950{ }^{\circ} \mathrm{C}-6 \mathrm{~h}$

Figure 5. Macro images of the crater formed after the adhesion test on AISI 304L samples pack-borided with microwave hybrid heating

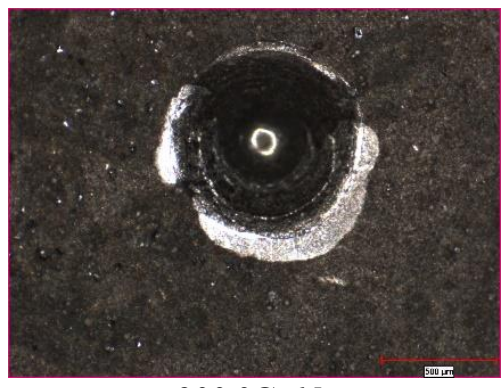

$900{ }^{\circ} \mathrm{C}-6 \mathrm{~h}$

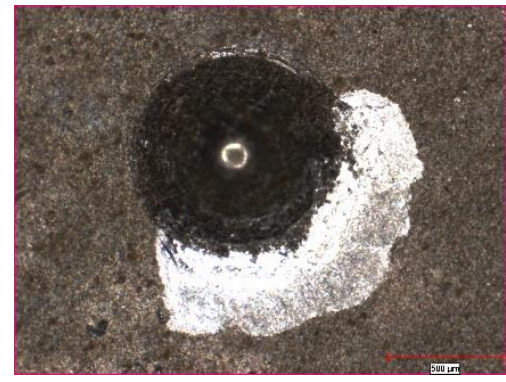

$950{ }^{\circ} \mathrm{C}-4 \mathrm{~h}$

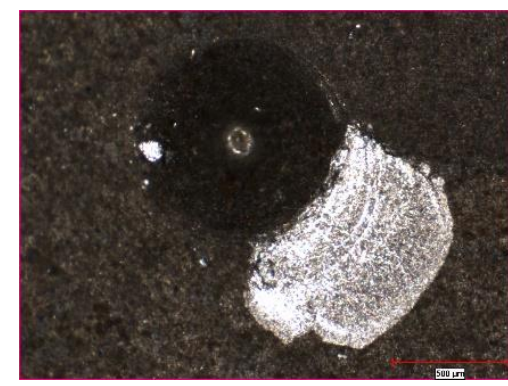

$950{ }^{\circ} \mathrm{C}-6 \mathrm{~h}$

Figure 6. Boride layer removals occurring after the adhesion test in AISI 304L samples pack-borided with

microwave hybrid heating

When the SEM images of the indentation traces of the boride layers of AISI 304L stainless steel samples packborided with microwave hybrid heating method in Figure 7-11 and Figure 14 are examined, it is more clearly seen that the acceptable damage in these samples

are HF1 quality micro cracks. These micro cracks are in the form of lateral cracks and generally capillary, and belong to the best quality category according to the VDI 3198 norm. Figure 12 shows the SEM image taken after the adhesion test of one of the AISI 304L samples pack- borided with microwave hybrid heating method at 900 ${ }^{\circ} \mathrm{C}$ with a retention time of 6 hours. It is seen that the adhesion strength quality belongs to the HF3 category due to the curvilinear cracks and occasional spallings in the boride layer on the surface of this sample. The SEM image taken after the adhesion test of another sample pack-borided at the same process temperature and time is given in Figure 13. There are spallation and wear debris in the boride layer of the sample. The adhesion strength of this sample between the boride layer and the base material is HF5 quality and is in unacceptable category. 


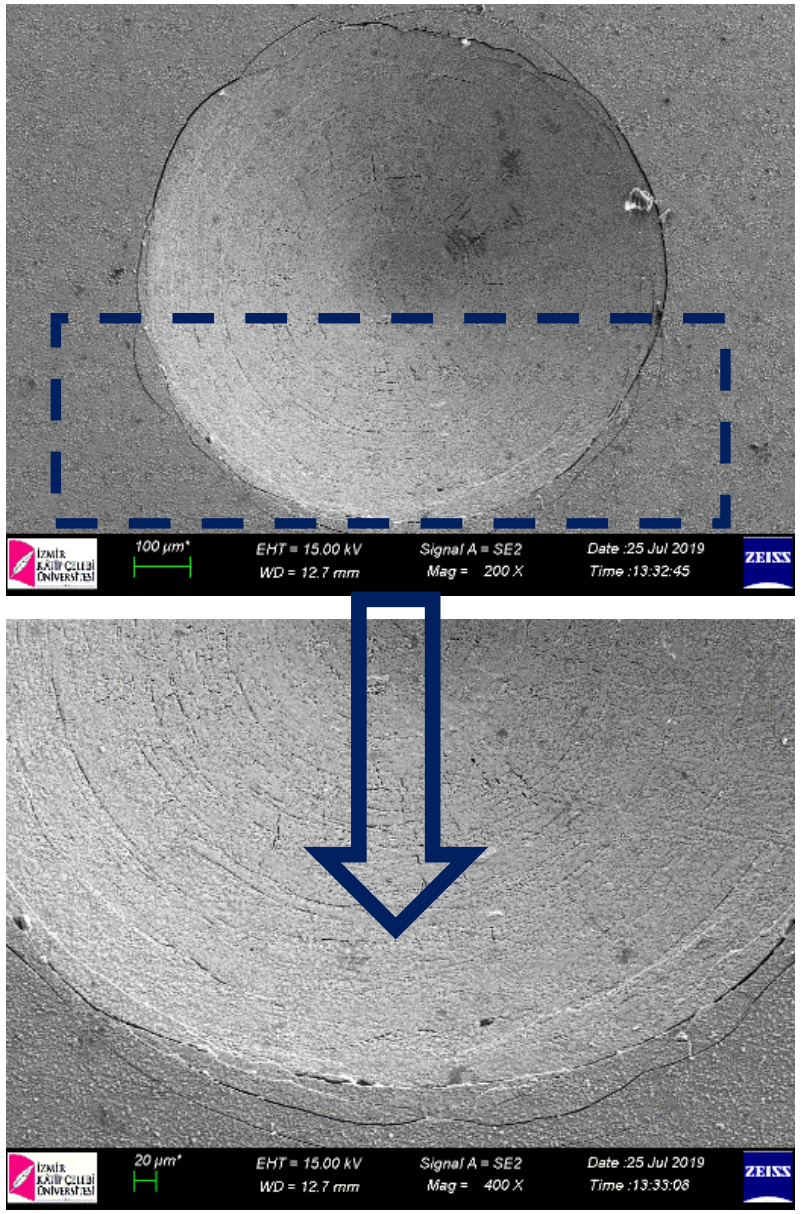

Figure 7. SEM images of the traces and micro cracks formed after the adhesion test on the AISI 304L sample pack-borided at $850{ }^{\circ} \mathrm{C}$ for 2 hours with microwave hybrid heating
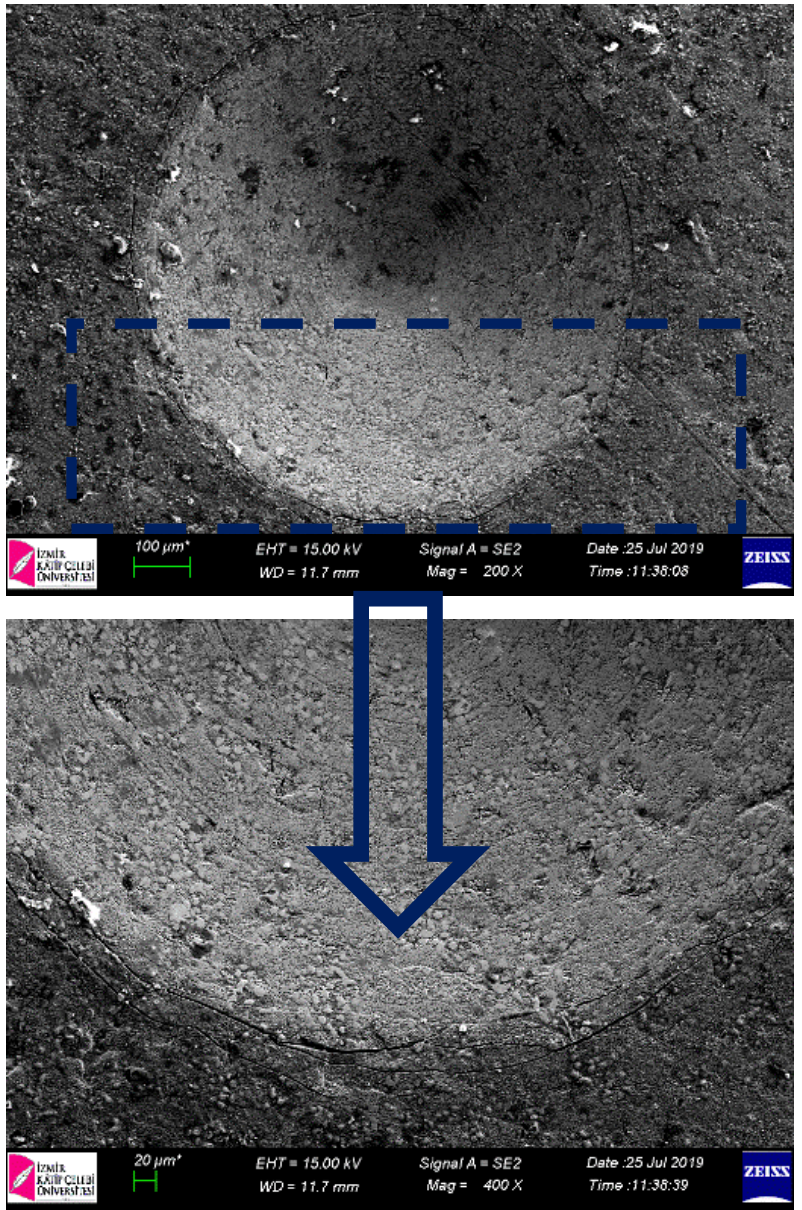

Figure 8. SEM images of the traces and micro cracks formed after the adhesion test in AISI 304L sample pack-borided at $850{ }^{\circ} \mathrm{C}$ for 4 hours with microwave hybrid heating

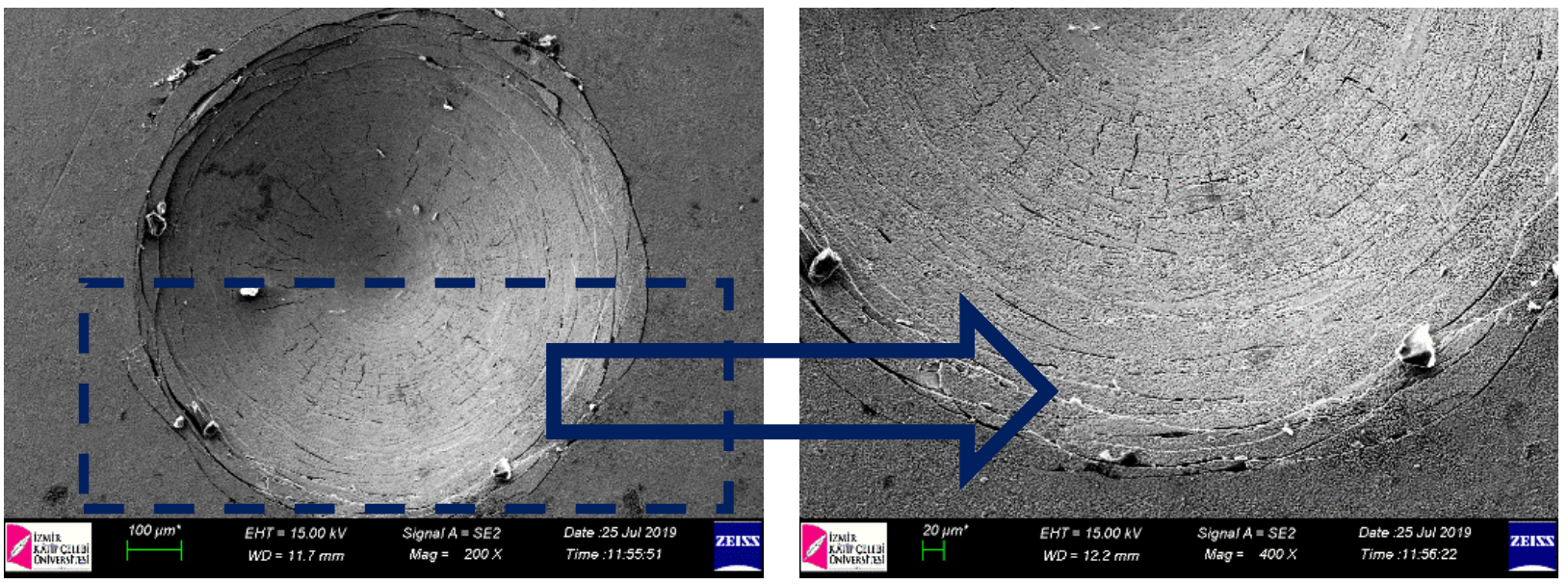

Figure 9. SEM images of the traces and micro cracks formed after the adhesion test on the AISI 304L sample packborided at $850{ }^{\circ} \mathrm{C}$ for 6 hours with microwave hybrid heating 

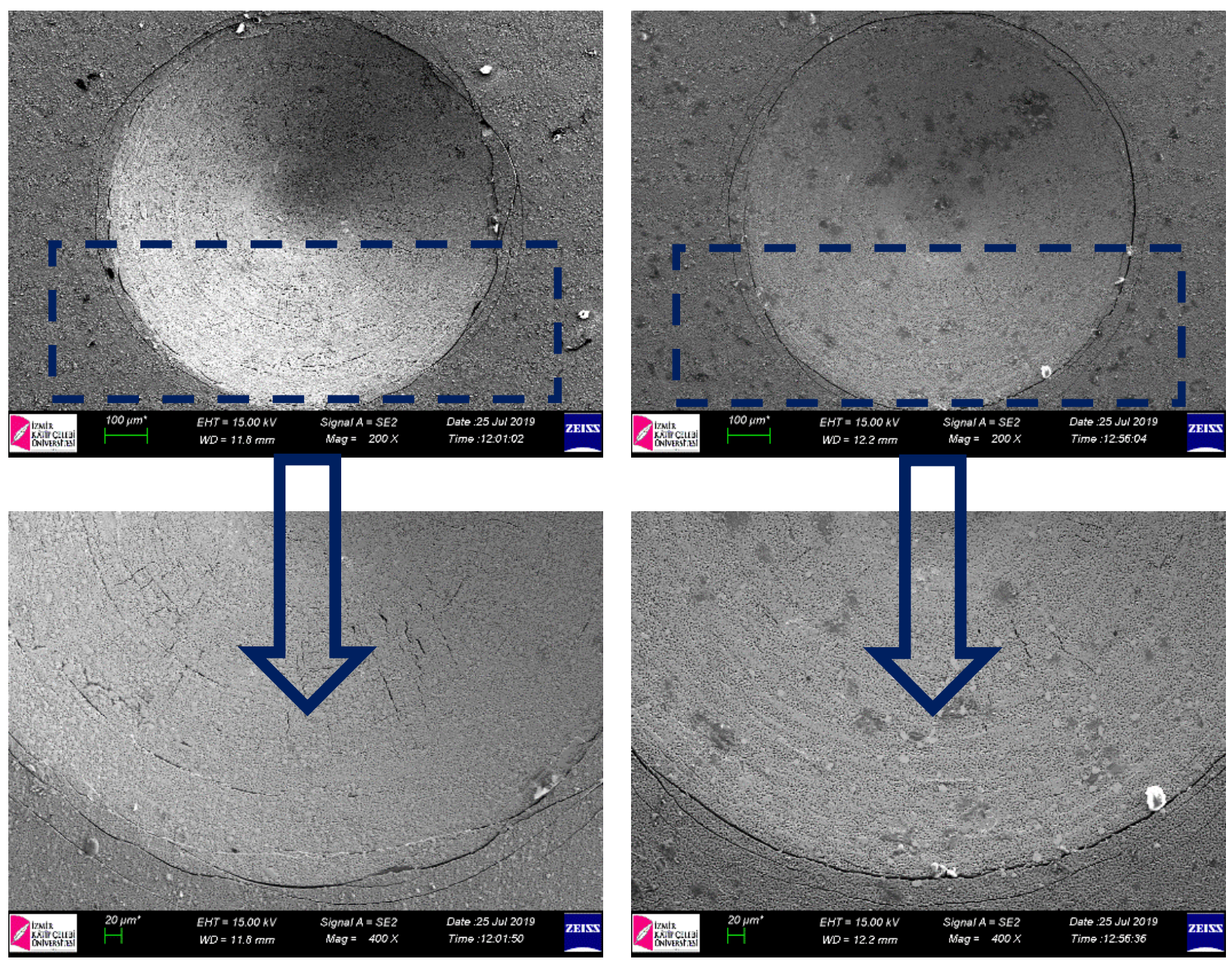

Figure 10. SEM images of the traces and micro cracks formed after the adhesion test in AISI 304L sample pack-borided at $900{ }^{\circ} \mathrm{C}$ for 2 hours with microwave hybrid heating

Figure 11. SEM images of the traces and micro cracks formed after the adhesion test in AISI 304L sample pack-borided at $900{ }^{\circ} \mathrm{C}$ for 4 hours with microwave hybrid heating

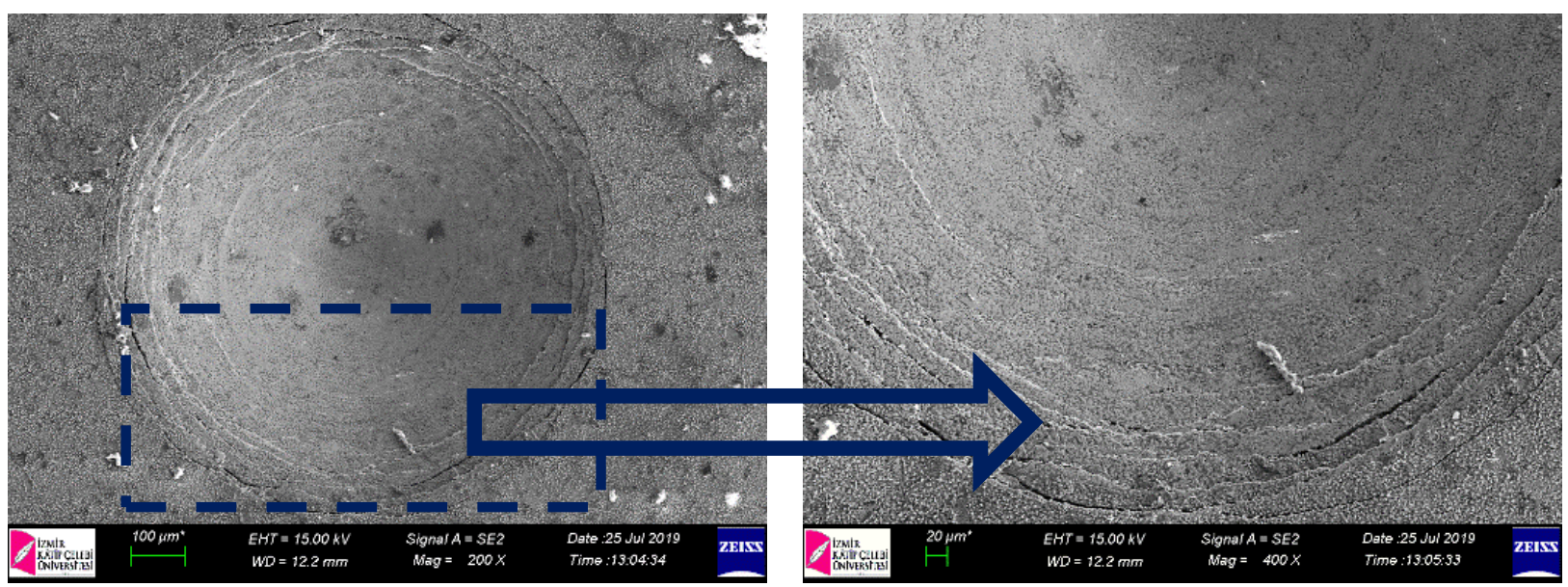

Figure 12. SEM images of the traces and micro cracks formed after the adhesion test on the AISI 304L sample pack-borided at $900{ }^{\circ} \mathrm{C}$ for 6 hours with microwave hybrid heating 

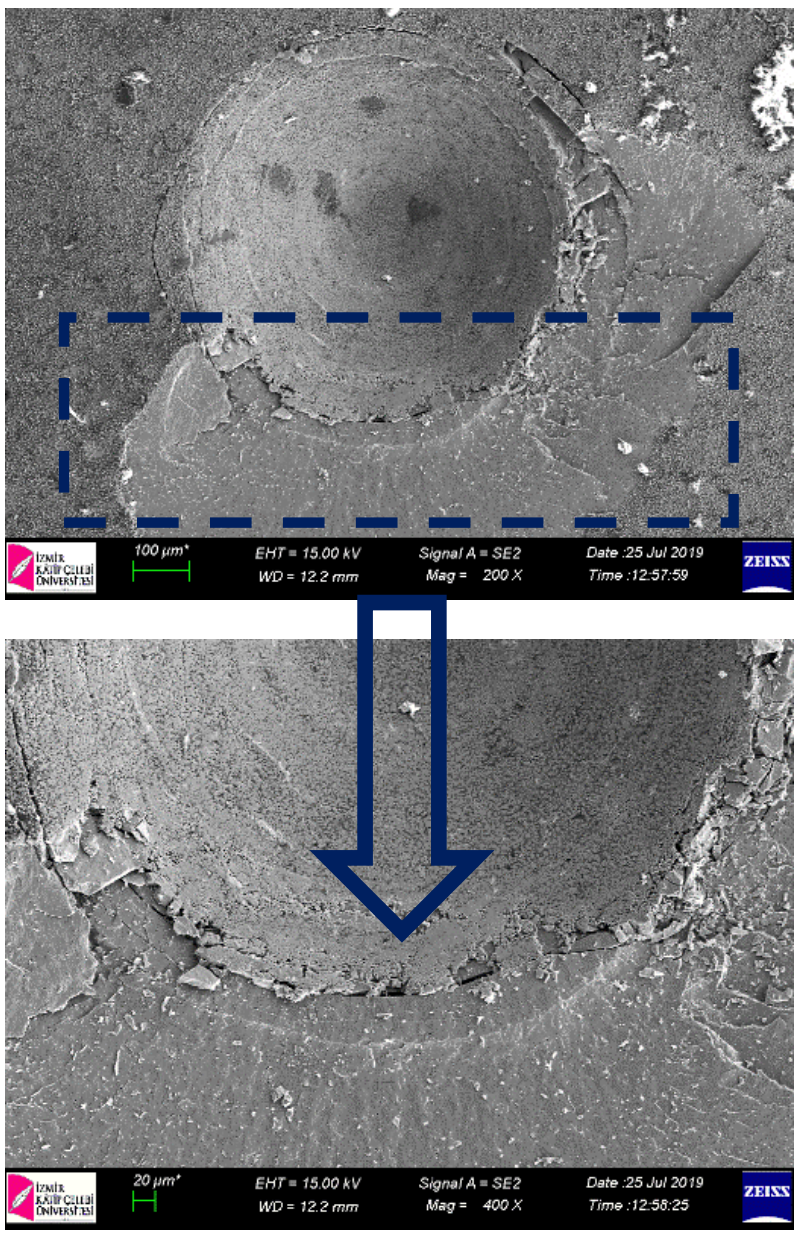

Figure 13. SEM images of the fracture formed after the adhesion test in AISI 304L sample pack-borided for 6 hours at $900{ }^{\circ} \mathrm{C}$ with microwave hybrid heating

The indentation craters belonging to one of the packborided samples with microwave hybrid heating at 950 ${ }^{\circ} \mathrm{C}$ for 4 hours are shown in Figure 15. There are abrasion scratches and burrs in the boride layer after the adhesion test. This damage is of HF3 type and is acceptable.

The damage appearance after the adhesion test of another sample, which is pack-borided with microwave hybrid heating at $950{ }^{\circ} \mathrm{C}$ for 4 hours, is shown in Figure 16. Delaminations occurred in the boride layer of the sample. According to the VDI 3198 indentation test principles, this damage is of the HF5 type and is unacceptable.

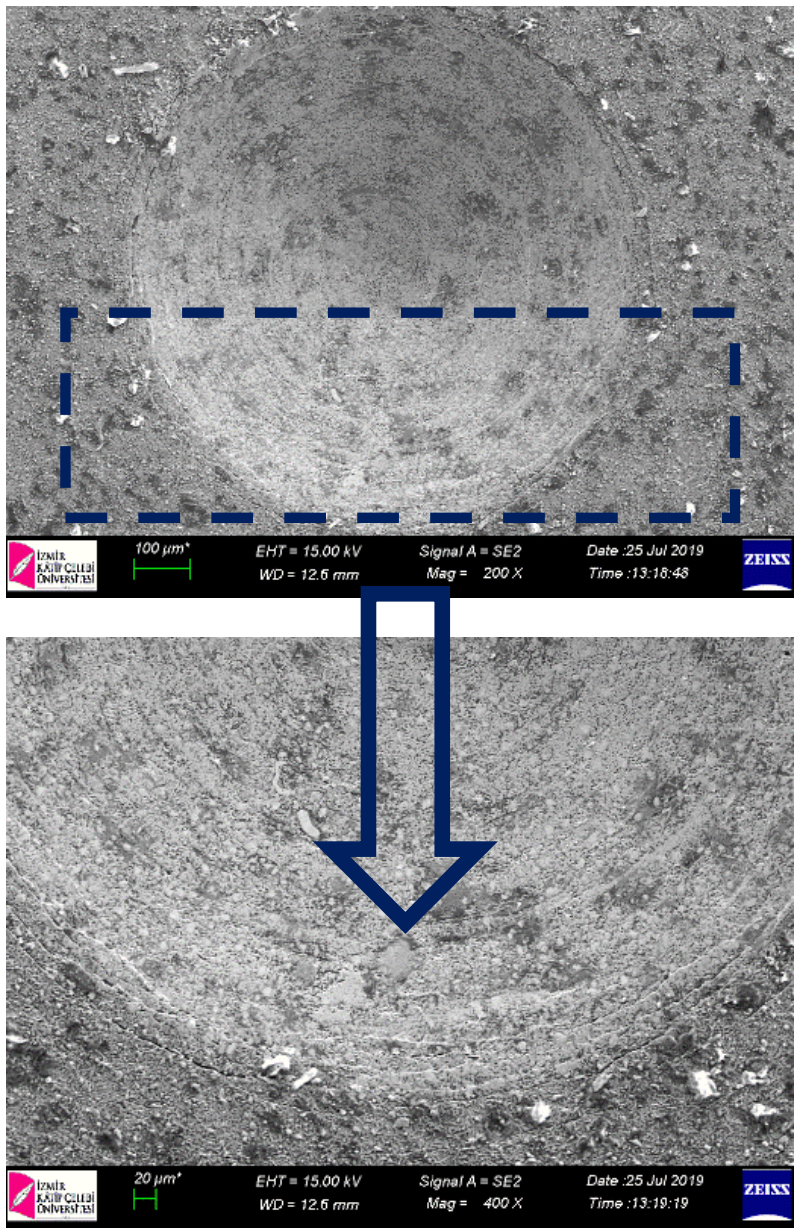

Figure 14. SEM images of the traces and micro cracks formed after the adhesion test of AISI 304L samples pack-borided at $950^{\circ} \mathrm{C}$ for 2 hours with microwave hybrid heating

The damage appearance after the indentation test of one of the samples pack-borided with microwave hybrid heating at $950{ }^{\circ} \mathrm{C}$ for 6 hours is given in Figure 17. Mosaic cracks and wear lines were formed in the boride layer. This damage is in the HF3 category and is acceptable.

The SEM image showing the damage appearance after the adhesion test of another sample that is pack-borided with microwave hybrid heating at $950{ }^{\circ} \mathrm{C}$ for 6 hours is given in Figure 18. Local spallation and delaminations occurred in the boride layer of the sample. According to the VDI 3198 indentation test principles, this damage is of the HF5 type and is unacceptable. 
Celal Bayar University Journal of Science

Volume 17, Issue 2, 2021, p 181-191

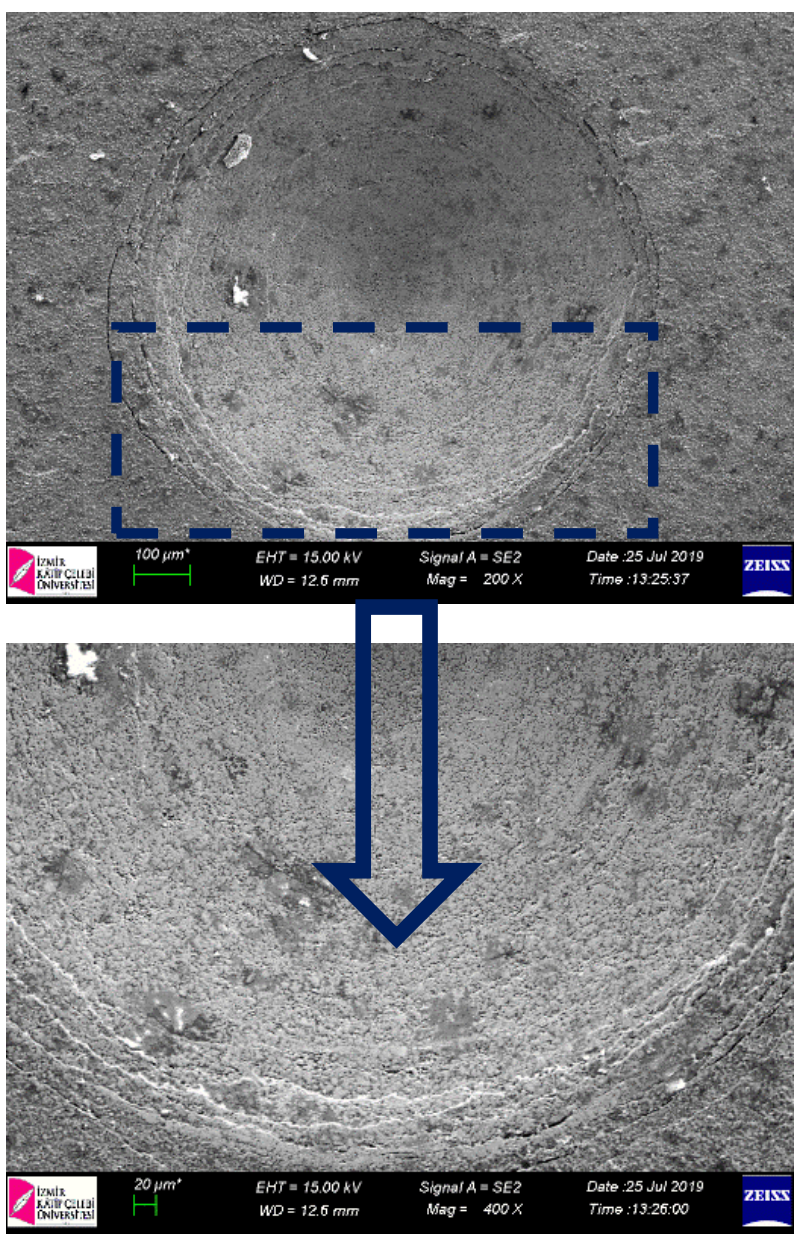

Figure 15. SEM images of the traces and micro cracks formed after the adhesion test of AISI 304L samples pack-borided at $950{ }^{\circ} \mathrm{C}$ for 4 hours with microwave hybrid heating
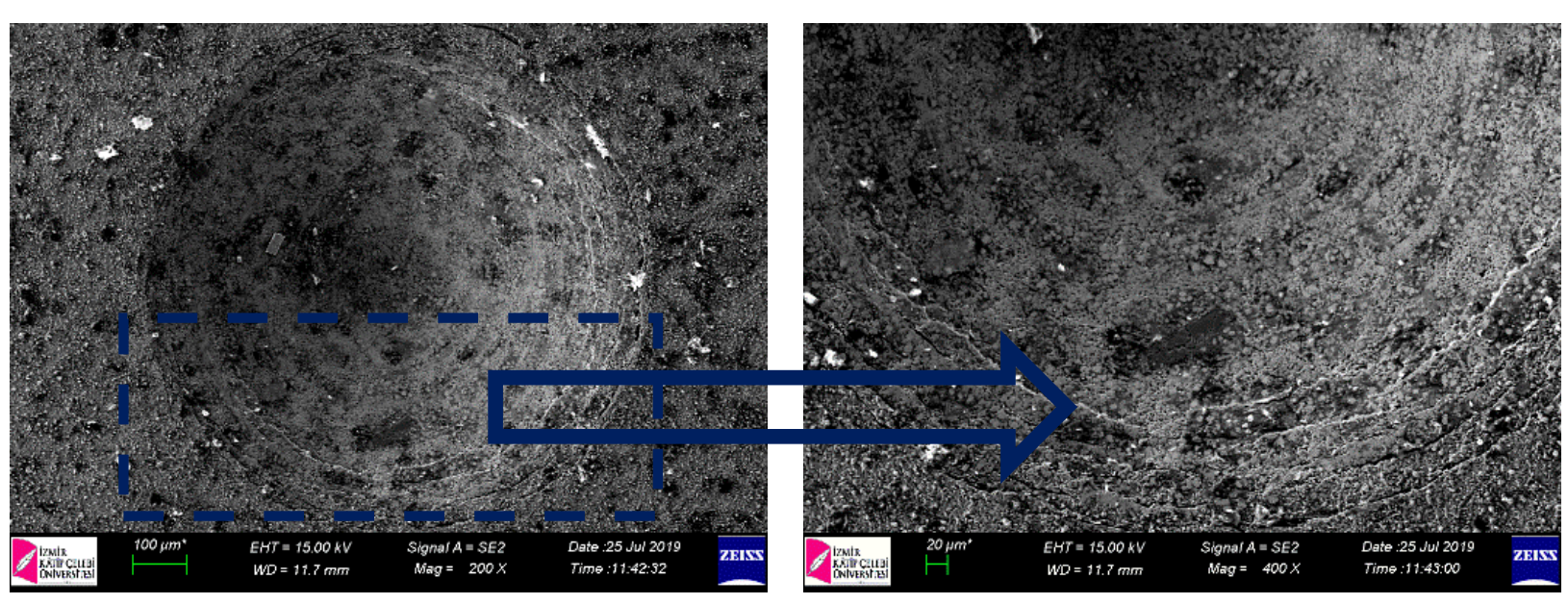

Figure 17. SEM images of the traces and cracks formed after the adhesion test of AISI 304L samples pack-borided at $950{ }^{\circ} \mathrm{C}$ for 6 hours with microwave hybrid heating
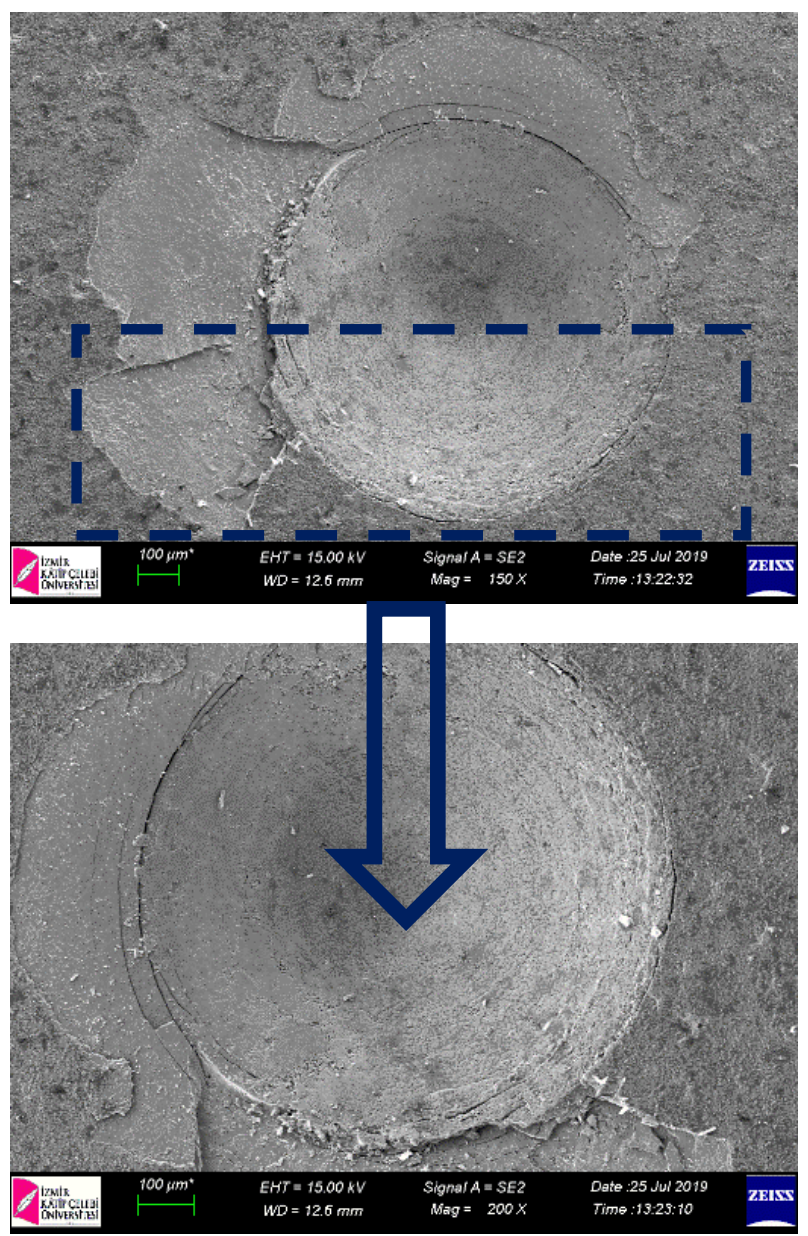

Figure 16. SEM images of the delaminations and cracks formed after the adhesion test of AISI 304L samples pack-borided at $950{ }^{\circ} \mathrm{C}$ for 4 hours with microwave hybrid heating 


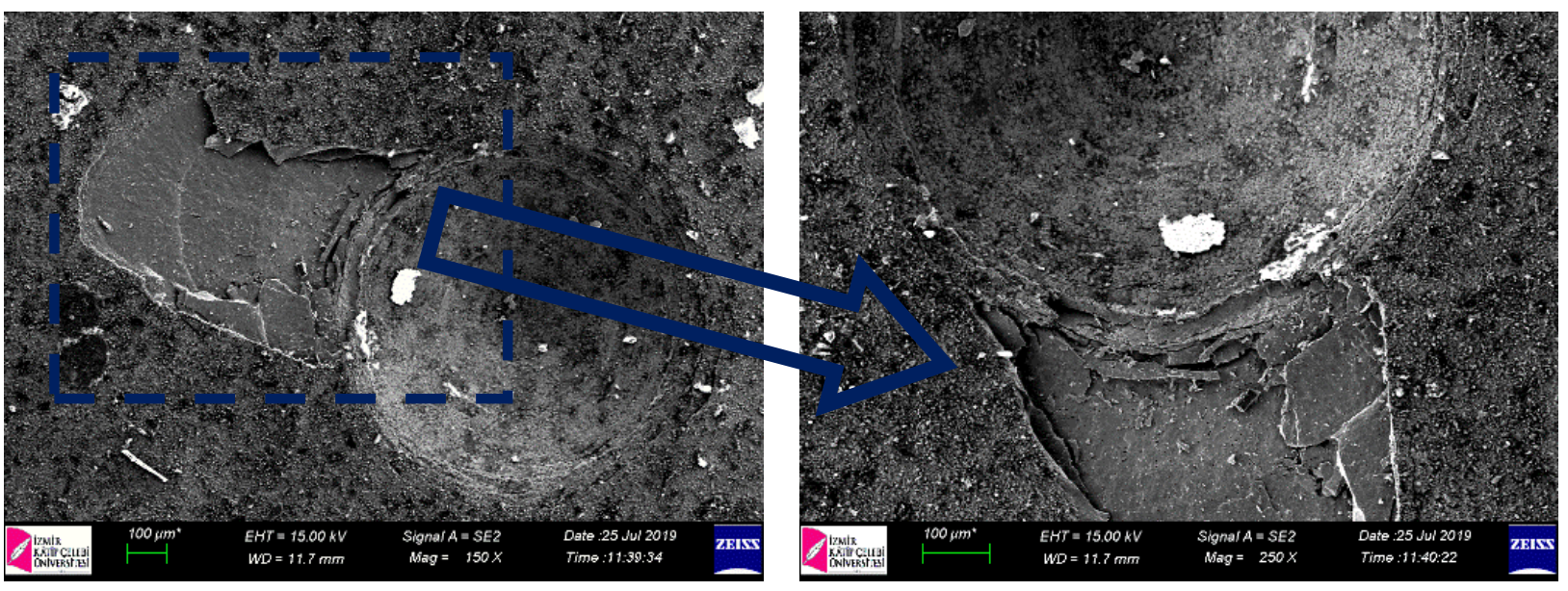

Figure 18. SEM images of the spallation and delaminations formed after the adhesion test of AISI 304L samples pack-borided at $950^{\circ} \mathrm{C}$ for 6 hours with microwave hybrid heating

\section{Conclusions}

Optical microscope examinations showed that both $\mathrm{FeB}$ and $\mathrm{Fe}_{2} \mathrm{~B}$ phase thicknesses increased with the increase of process temperature and retention time in packboriding processes performed with microwave hybrid heating method. Uniform and homogeneous boride layers were obtained. However, boride layers formed by the effect of alloying elements are not saw-toothed but flat structure.

XRD pattern analysis showed the presence of $\mathrm{FeB}$, $\mathrm{Fe}_{2} \mathrm{~B}, \mathrm{Cr}_{2} \mathrm{~B}$ and $\mathrm{Ni}_{2} \mathrm{~B}$ phases in the boride layer.

As a result of the Daimler-Benz Rockwell-C adhesion tests carried out, the adhesion strength of the boride layers-substrate of all samples is high, except for the samples that are pack-borided for 6 hours at $900{ }^{\circ} \mathrm{C}$, and at $950{ }^{\circ} \mathrm{C}$ for 4 and 6 hours with microwave hybrid heating because the adhesion has decreased with increasing boriding temperature and time. The main reason for the low adhesion strength in these samples is the delamination and spallation of the boride layer as a result of the increase in the thickness of the brittle $\mathrm{FeB}$ phase due to the increase in the temperature and retention time of the pack-boriding process.

\section{Author's Contributions}

Dilek Arslan: Carried out the experimental processes and examined the results. The manuscript was drafted and written by her.

Recep Onur Uzun: Supervised the experimental procedure and contributed to manuscript preparation.

\section{Ethics}

There are no ethical issues after the publication of this manuscript.

\section{References}

1. Morón, RC, Hernández-Onofre, I, Contla-Pacheco, AD, BravoBárcenas, D, Campos-Silva, I. 2020. Friction and reciprocating wear behavior of borided AISI H13 steel under dry and lubricated conditions. Journal of Materials Engineering and Performance; 29: 4529-4540.

2. Kayali, Y, Büyüksagis, A, Yalcin, Y. 2013. Corrosion and wear behaviors of boronized AISI 316L stainless steel. Metals and Materials International; 19(5): 1053-1061.

3. Alias, SK, Abdullah, B, Talari, M, Jumadin, MH, Idham, MF, Ismail, A. 2017. Effect of pack boronizing on microstructure and microhardness of 304 stainless steel. Key Engineering Materials; 740: 54-59.

4. Kayali, Y. 2013. Investigation of the diffusion kinetics of borided stainless steels. The Physics of Metals and Metallography; 114(12): 1061-1068.

5. Günen, A, Kurt, B, Somunkıran, İ, Kanca, E, Orhan, N. 2015. The effect of process conditions in heat-assisted boronizing treatment on the tensile and bending strength characteristics of the AISI-304 austenitic stainless steel. The Physics of Metals and Metallography; 116(9): 896-907.

6. Calik, A, Simsek, M, Karakas, MS, Ucar, N. 2014. Effect of boronizing on microhardness and wear resistance of steel AISI 1050 and chilled cast iron. Metal Science and Heat Treatment; 56: 89-92.

7. Yilmaz, SO, Teker, T, Karatas, S. 2016. Wear behavior of iron boride coating on AISI 4140. Protection of Metals and Physical Chemistry of Surfaces; 52(1): 119-127.

8. Gunes, I. 2013. Wear behaviour of plasma paste boronized of AISI 8620 steel with borax and $\mathrm{B}_{2} \mathrm{O}_{3}$ paste mixtures. Journal of Materials Science \& Technology; 29(7): 662-668.

9. Ulutan, M, Celik, ON, Gasan, H, Er, U. 2010. Effect of different surface treatment methods on the friction and wear behavior of AISI 4140 steel. Journal of Materials Science \& Technology; 26(3): 251-257.

10. Béjar, MA, Moreno, E. 2006. Abrasive wear resistance of boronized carbon and low-alloy steels. Journal of Materials Processing Technology; 173: 352-358. 
11. Carrera-Espinoza, R, Figueroa-López, U, Martínez-Trinidad, J, Campos-Silva, I, Hernández-Sánchez, E, Motallebzadeh, A. 2016. Tribological behavior of borided AISI 1018 steel under linear reciprocating sliding conditions. Wear; 362-363: 1-7.

12. Tabur, M, Izciler, M, Gul, F, Karacan, I. 2009. Abrasive wear behavior of boronized AISI 8620 steel. Wear; 266: 1106-1112.

13. Aichholz, SAC, Meruvia, MS, Júnior, PCS, Torres, RD. 2018 Tribocorrosion behavior of boronized AISI 4140 steel. Surface and Coatings Technology; 352: 265-272.

14. Bartkowska, A, Bartkowski, D, Swadźba, R, Przestacki, D, Miklaszewski, A. 2018. Microstructure, chemical composition, wear, and corrosion resistance of $\mathrm{FeB}-\mathrm{Fe}_{2} \mathrm{~B}-\mathrm{Fe}_{3} \mathrm{~B}$ surface layers produced on Vanadis- 6 steel using $\mathrm{CO} 2$ laser. The International Journal of Advanced Manufacturing Technology; 95: 1763-1776.

15. Gunes, I, Ulker, S, Taktak, S. 2011. Plasma paste boronizing of AISI 8620, 52100 and 440C steels. Materials and Design; 32: 2380-2386.

16. Kayali, Y, Günes, I, Ulu, S. 2012. Diffusion kinetics of borided AISI 52100 and AISI 440C steels. Vacuum; 86: 1428-1434.

17. Ozbek, I, Sen, S, Ipek, M, Bindal, C, Zeytin, S, Ucisik, AH. 2004 A mechanical aspect of borides formed on the AISI $440 \mathrm{C}$ stainless-steel. Vacuum; 73: 643-648.

18. Günen, A, Kanca, E, Demir M, Er, Y, Sağlam, G, Gök, MS. 2017. Micro-abrasion wear behavior of fast borided steel tooth drill bits. Tribology Transactions; 60(2): 267-275.

19. Gunes, I, Kanat, S. 2015. Diffusion kinetics and characterization of borided AISI D6 steel. Protection of Metals and Physical Chemistry of Surfaces; 51(5): 842-846.

20. Akkaş, M, Islak, S, Özorak, C. 2018. Corrosion and wear properties of $\mathrm{Cu}$-TiC composites produced by hot pressing technique. Celal Bayar University Journal of Science; 14(4): 465469.

21. Kumar, GBV, Rao, CSP, Selvaraj, N. 2011. Mechanical and Tribological Behavior of Particulate Reinforced Aluminum Metal Matrix Composites - a review. Journal of Minerals \& Materials Characterization \& Engineering; 10(1): 59-91.

22. Taktak, S, Tasgetiren S. 2006. Identification of Delamination Failure of Boride Layer on Common Cr-Based Steels. Journal of Materials Engineering and Performance; 15(5): 570-574.

23. Krelling, AP, Costa, CE, Milan, JCG, Almeida, EAS. 2017. Micro-abrasive wear mechanisms of borided AISI 1020 steel. Tribology International; 111: 234-242.

24. Vidakis, N, Antoniadis, A, Bilalis, N. 2003. The VDI 3198 indentation test evaluation of a reliable qualitative control for layered compounds. Journal of Materials Processing Technology; 143-144: 481-485.

25. Verein Deutscher Ingenieure Normen, VDI 3198, VDI-Verlag, Dusseldorf, 1991. 